\title{
Red Blood Cell Alloimmunization in Sickle Cell Disease Patients in Jeddah, Saudi Arabia: A Pilot Study
}

\author{
Abdulrahman S. Alboog ${ }^{1}$, MBBS, Taher M. Tayeb' ${ }^{2}$, MBBS, \\ Mohammed O. Alsager ${ }^{2}$, MBBS, Salwa A AINajjar ${ }^{3}$, PhD, Ghazi A. Damanhouri, ${ }^{3,4}$, \\ FRCPA, FRCPath, Jummanah S. Jarullah ${ }^{4}$, PhD, and Salwa I. Hindawi ${ }^{3}$, FRCPath, CTM \\ Departments of ${ }^{1}$ Anesthesia and Critical Care, ${ }^{2}$ Medicine, and ${ }^{3}$ Hematology, Faculty of Medicine \\ ${ }^{4}$ Hematology Research Unit, King Fahd Medical Research Centre \\ King Abdulaziz University, Jeddah, Saudi Arabia
}

\section{Correspondence \\ Dr. Jummanah S. Jarullah \\ P.O. Box 80216, Jeddah 21589, Saudi Arabia \\ e.M: jjarwllah@kau.edu.sa \\ Submission: 15 Apr. 2015 \\ Accepted: 18 Jun. 2015}

\section{Citation}

Alboog AS, Tayeb TM, Alsager MO, AlNajjar SA, Damanhouri GA, Jarullah JS, Hindawi SI. Red blood cell alloimmunization in sickle cell disease patients in Jeddah, Saudi Arabia: a pilot study. JKAU Med Sci 2015; 22 (3): 35-40. DOI: 10.4197/Med. 22.3.5

\begin{abstract}
The treatment of patients with sickle cell disease frequently requires transfusion of red blood cells. Complications due to alloimmunization of red blood cells antigen remain a major risk as a post transfusion effect. The objective of this study is to determine the frequency of red cell alloimmunization in Jeddah, Saudi Arabia. A retrospective cross-section study of sickle cell disease patients at King Abdulaziz University Hospital between 2012-2013 was performed. Demographic characteristics and transfusion history was recorded. Blood samples were analysed for alloimmunization using immunohematological technique. A total of 234 sickle cell patients were analysed, of which $30(12.8 \%)$ showed alloantibodies. A total of 43 alloantibodies were found out of which 28 belonged to Rh group, eight belonged to Kell while three belonged to MNS group. Demographic and transfusion characteristics were analysed between alloimmunized and nonalloimmunized sicklecell disease patients. The rate of alloimmunization in Jeddah, Saudi Arabia was $12.8 \%$. There was significant difference observed between alloantibodies detection between transfused patients compared to non-transfused patients. The consequences of red blood cell allommunization are highly significant and therefore immune haematological testing is highly recommended.
\end{abstract}

\section{Keywords}

Alloimmunization; Sickle cell disease; Red blood cell; Transfusion

\section{Introduction}

W ith the advancement in availability of erythrocytapheresis and improved methods to treat with iron overload, transfusion therapy is increasingly used for the treatment of sickle cell disease (SCD). Red blood cell alloantibody formation remains a major complication for patients with SCD, making blood transfusion a medical challenge. With the increased use of transfusion techniques for the management 
of SCD patients, the alloimmunization issue becomes imperative. The incidence of alloimmunization in SCD patients ranges from $7 \%$ to $47 \%$ depending on age, ethnicity, gender, RBC exposure and antigen mismatch ${ }^{[1-5]}$. Out of those who possess alloantibodies 4-11\% have delayed hemolytic transfusion reactions $(\mathrm{DHTR})^{[6]}$

In the United States multiple red blood cell RBC alloimmunization antigens were detected in more than $50 \%$ of alloimmunized subjects ${ }^{[7]}$. Similar reports have been documented from Brazil with 50\% of the patients with SCD (56 out of 108) exhibiting alloimmunization $^{[8]}$. However in Uganda, only $6.1 \%$ possessed alloantibodies ${ }^{[9]}$. Studies in Eastern Saudi Arabia documented alloantibodies in $13.7 \%{ }^{[10]}$ while another similar study revealed an alloimmunization rate of $34.2 \%{ }^{[11]}$

The Rhesus (Rh) system comprising of two homologous genes, RHD and RHCE which encode $D$ antigen and $C E$ antigens in various combinations includes 50 different serological specificities ${ }^{[12]}$. Along with $\mathrm{Rh}$ and $\mathrm{K}$ antigen, minor antigens in Kidd, Duffy and MNS are found at lower rates ${ }^{[13]}$. One approach to minimize alloimmunization is to transfuse phenotypic matched RBC to the SCD patients.

Indications for transfusion include acute aplastic crisis, acute splenic or hepatic sequestration, symptomatic anemia, stroke treatment and prevention, acute chest syndrome treatment and prevention, and before preparation for major surgery ${ }^{[14,15]}$. Randomized controlled trials have demonstrated that prophylactic red cell transfusions significantly decrease the frequency of stroke events in at-risk paediatric patients with $S C D^{[16]}$.

The objective of this study was to establish the frequency, and characterize the nature of, RBC alloimmunization in SCD patients of Saudi Arabia.

\section{Materials and Methods}

\section{Patients}

This is a retrospective cross-sectional study carried out at King Abdulaziz University Hospital between 2012 and 2013 comprised of patients coming to the hematology outpatient clinic. Informed consent was obtained from the patients or their parents/ guardians. All the SCD patients were eligible for this study. However, those SCD patients having other complications were excluded from the study. A total of 234 SCD patients' medical records were reviewed. Patients' demographics were analysed and classified according to age, sex, gender, ethnicity, blood group, transfusion history, splenectomy, antibody formation and mortality.

\section{Laboratory Investigation}

Blood was drawn from the patients and plasma samples were screened for the presence of RBC antibodies with polyspecific anti human globulin. Gel technique was used for detection and identification of antibodies. Patients' RBCs were serologically phenotyped before transfusion for ABO; Rh (D, C, C ,E, e); Kell (K); Duffy (Fy'. Fy $\left.{ }^{b}\right)$; Kidd $\left(\mathrm{Jk}^{\mathrm{a}}, \mathrm{JK}^{\mathrm{b}}\right)$; Lewis $\left(\mathrm{Le}^{\mathrm{a}}\right.$, Le $\left.{ }^{\mathrm{b}}\right)$; MNS $(\mathrm{M}, \mathrm{N}, \mathrm{S}, \mathrm{s})$ and PI.

\section{Statistical Analysis}

Statistical analysis was performed using IBM SPSS Statistics for Windows, Version 20. (IBM Corp., Armonk, NY USA). Significance and frequency tests were performed on alloimmunized and non alloimmunized patients regarding all the parameters. Groups were assumed to be significant when probability level was less than 0.05 .

\section{Results}

Study period was 2012 to 2013, and 234 sickle cell patients were screened for the presence of alloantibodies. $\quad 30(12.8 \%)$ out of 234 showed alloimmunobodies. Out of the 30 patients showing alloantibodies, 28 were $\mathrm{Rh}+$ and 2 were Rh-. The demographic and transfusion characteristic of SCD patients are given in Table 1. The specification of alloantibodies identified in the 30 SCD patients is given in Table 2.

\section{Discussion}

Despite improved patient management with hydroxyurea, transfusion technique of management is associated with a considerable reduction in morbidity and mortality of SCD patients. Conversely, transfusion brings serious complications due to erythrocytes alloimmunization. This study reveals the frequency and nature of alloimmunization in post transfused SCD patients in Jeddah Saudi Arabia. It is the first study in Western Saudi Arabia accounting the presence of, quantity, and type of antibodies in SCD patients. Out of the total 234 SCD patients 131 were male and 103 were female. The mean age was 24 (range, 7-54). The patients were transfused between 
RBC Alloimmunization in SCD

A.S. Alboog et al.

Table 1. Demographic and transfusion characteristic of SCD patients in Saudi Arabia.

\begin{tabular}{|c|c|c|c|c|c|}
\hline \multirow{2}{*}{ Demographic } & \multicolumn{2}{|c|}{ Alloimmunized Patients } & \multicolumn{2}{|c|}{ Non-Alloimmunized Patients } & \multirow{2}{*}{$\frac{p \text {-Value }}{\text { NS }}$} \\
\hline & No of Patients & $\%$ & No of Patients & $\%$ & \\
\hline No of Patients & 30 & $12.80 \%$ & 204 & $87.20 \%$ & NS \\
\hline Female/Male & $14 / 16$ & $46.70 \% / 53.30 \%$ & $89 / 115$ & $43.60 \% / 56.40 \%$ & NS \\
\hline Saudi/Non Saudi & $6 / 24$ & $20.00 \% / 80.00 \%$ & $98 / 106$ & $48.00 \% / 52.00 \%$ & NS \\
\hline Age in Years & $10-42$ & & $7-54$ & & \\
\hline Transfusion Episode & 20 & $66.60 \%$ & 91 & $44.60 \%$ & $0.026^{\dagger}$ \\
\hline 3-4 weeks & 3 & $10.00 \%$ & 16 & $7.80 \%$ & \\
\hline 5-7 weeks & 6 & $20.00 \%$ & 17 & $8.30 \%$ & \\
\hline$\geq 8$ weeks & 11 & $36.60 \%$ & 58 & $28.40 \%$ & \\
\hline No of Transfusions & 10 & $33.30 \%$ & 113 & $55.40 \%$ & \\
\hline Deceased & 1 & $3.30 \%$ & 8 & $3.90 \%$ & NS \\
\hline Rh Positive/Rh Negative & $28 / 2$ & $93.00 \% / 7.00 \%$ & $189 / 15$ & $92.60 \% / 7.40 \%$ & NS \\
\hline \multicolumn{6}{|l|}{ ABO Blood Group } \\
\hline A & 15 & $50.00 \%$ & 62 & $30.40 \%$ & NS \\
\hline$B$ & 2 & $6.70 \%$ & 24 & $11.80 \%$ & NS \\
\hline 0 & 12 & $40.00 \%$ & 108 & $52.90 \%$ & NS \\
\hline$A B$ & 1 & $3.30 \%$ & 10 & $4.90 \%$ & NS \\
\hline Spleenectomy & & & & & NS \\
\hline Yes & 4 & $13.30 \%$ & 15 & $7.40 \%$ & \\
\hline No & 26 & $86.70 \%$ & 189 & $92.60 \%$ & \\
\hline
\end{tabular}

P values comparing the continuous variables were obtained by independent-samples t-test, IBM SPSS Statistics for Windows, Version 20.

Significance $p<0.05 ;$ NS= Non Significant

Table 2. Specificities of 43 RBC alloantibodies identified in 30 patients in Saudi Arabia.

\begin{tabular}{|c|c|c|c|}
\hline Blood Group System & $\begin{array}{c}\text { RBC Alloantibody (Percentage of } \\
\text { Alloantibodies Identified) }\end{array}$ & RBC Alloantibody Specificity & $\begin{array}{c}\text { Number of Antibodies } \\
\text { (Respectively) }\end{array}$ \\
\hline $\mathrm{Rh}$ & 65 & $\mathrm{E}, \mathrm{D}, \mathrm{C}$ & $16,2,10$ \\
\hline MNS & 18.6 & SM & 2,1 \\
\hline Kell & 7 & K & 8 \\
\hline Duffy & 4.6 & Fy & 2 \\
\hline Lewis & 2.3 & $\operatorname{Le}^{a}$ & 1 \\
\hline Luth & 2.3 & $L u^{\mathrm{a}}$ & 1 \\
\hline
\end{tabular}

3-4 weeks, 5-6 weeks or after 8 weeks according to the requirement. Thirty $(12.8 \%)$ patients were found to be alloimmunized to RBC antigens. The frequency of alloimmunization in different populations ranges considerably depending on various factors. In the United Kingdom, United States, Brazil and Kuwait the documented alloimmunization rates in patients with SCD was between $18-76 \%[3,8,17-19]$, while in Africa it showed $6.1 \%{ }^{[9,20]}$. In a Michigan study the frequency rate of RBC alloimmunization was reported to be $5.3 \%$ unlike other United States studies. Studies carried out in Eastern Saudi Arabia on SCD patients documented alloantibodies in $13.7 \%$ (48 out of 350 ) while another similar study revealed an alloimmunization rate of $34.2 \%$ (38 out of 111 ) ${ }^{[10]}$. The results of the first study are similar to this study. However the older study shows a higher rate of alloimmunization, which could be due to the smaller sample size.
The varied range of alloimmunization is due to racial and ethnic differences between donors and recipients of transfused $\mathrm{RBC}$. The greater the genotypic antigenic mismatch, the higher the alloimmunization is instigated. In Saudi Arabia there is a mixed population and there is a strong possibly of mismatches.

Age has been correlated with the risk of alloimmunization by Rosse et al. ${ }^{[20]}$. The study describes a higher frequency in children who receive transfusion after the age of 10. However in the present study, all the patients showing alloimmunzation were above 10 years. There was no significant difference between the age of patients who developed antibodies and those who did not develop alloantibodies (Table 1). Similar results were documented by Dias Zanette et al. ${ }^{[8]}$ in 2010 showing that the age of the first transfusion had 
no significant difference between alloimmunized and non alloimmunized patients. There were 16 males and 14 females in the alloimmunized group, while 115 males and 89 females were in the non alloimmunized group. There was no significant difference between the two groups and also no difference within the groups. All the other demographic data are given in Table 1. Those patients who got transfusion showed significantly higher antibodies compared to those not transfused. All other parameters showed no significant differences.

The total number of immune antibodies found in this study were 43, out of which Rh and Kell group showed maximum antigen, the rest belong to MNS, Duffy, Lewis and Luth antigens. Table 2 shows the specificity of antibodies identified, with the Rh blood group system having 28 (65\%) antibodies, Kell being the next frequent blood group involved with 8 (18.6\%) alloantibodies, while MNS was the next frequent blood group contributing $3(7 \%)$ alloantibodies. Finally Duffy, Lewis and Luth showed 2 (4.6\%), 1 (2.3\%) and 1 (2.3\%) alloantibodies, respectively.

In the alloimmunized patients, two patients were Rh D negative blood type. One patient was detected having alloantibody $C$ and $D$ of Rh blood group system while a second patient showed only alloanti-D. As a referral hospital we do receive patients who have a previous history of blood transfusion in another hospital and subsequently developed a complication of antibodies to red cells. Patients also tend to move between hospitals to receive blood. In all hospitals antibody screening is not done. We recommend that national guidelines, policies and training of staff should be encouraged to improve blood transfusion services and to minimize red cell antibodies in transfusion dependent patients.

The National Institutes of Health recommends that a RBC phenotype (ABO, Rh, Kell, Duffy, Kidd, Lewis, Lutheran, $\mathrm{P}$, and MNS at a minimum) be obtained on all patients with SCD older than 6 months ${ }^{[21]}$. To prevent alloimmunization in SCD patients, the standard practice is to perform antigen matching for $C, E$ and $K^{[2]}$. In the present study, we have maximum alloimmunity from the antigen recommended by National Institutes of Health. Therefore the similar strategy can be applied with additional $\mathrm{S}$ antigen testing of MNS system. The only limitation of this study is the small sample size. A similar study with increased sample size is our subsequent targeted study.

\section{Conclusion}

To improve and manage the consequences of alloantibodies in sickle cell patients, performing an antibody screen with subsequent antibody identification is obligatory for all transfused patients at King Abdulaziz University Hospital and a few other hospitals in Saudi Arabia. The testing should be done for $\mathrm{RH}$ and Kell blood group system as mandatory, while MNS, Duffy, Lewis, Kidd and Luth blood group system is advisable. Transfusion medicine specialists can play an important role by making this a routine practice for the welfare of SCD patients. Transfusion problems can be largely excluded by the execution of preventive measures. There is a large variation in transfusion management among paediatric hematologists and related practices ${ }^{[22]}$. The development of comprehensive guidelines and protocols for transfusion requirements in SCD must be developed and practiced globally. There is an explicit need for prospective clinical trials addressing phenotype matched blood transfusion in SCD patients.

\section{Conflict of Interest}

The authors have no conflict of interest.

\section{Disclosure}

None of the authors received any type of commercial support either in forms of compensation or financial for this study. They have no financial interest in any of the products or devices, or drugs mentioned in this article.

\section{Ethical Approval}

Obtained.

\section{References}

[1] Lasalle WM, Nuss R, Le T, Cole L, Hassell K, Murphy JR, Ambruso DR. Extended red blood cell antigen matching for transfusions in sickle cell disease: a review of a 14-year experience from a single center (CME). Transfusion 2011 51(8): 1732-1739.

[2] Miller ST, Kim HY, Weiner DL, Wager CG, Gallagher D, Styles LA, Dampier CD, Roseff SD; Investigators of the Sickle Cell Disease Clinical Research Network (SCDCRN). Red blood cell alloimmunization in sickle cell disease: prevalence in 2010. Transfusion. 2013; 53(4): 704-709.

[3] Sakhalkar VS, Roberts K, Hawthorne LM, McCaskill DM, Veillon DM, Caldito GC, Cotelingam JD. Allosensitization 
RBC Alloimmunization in SCD

A.S. Alboog et al.

in patients receiving multiple blood transfusions. Ann N Y Acad Sci. 2005; 1054: 495-499.

[4] Wahl SK, Garcia A, Hagar W, Gildengorin G, Quirolo K, Vichinsky E. Lower alloimmunization rates in pediatric sickle cell patients on chronic erythrocytapheresis compared to chronic simple transfusions. Transfusion 2012; 52(12): 2671-2676

[5] O'Suoji C, Liem Rl, Mack AK, Kingsberry P, Ramsey G, Thompson AA. Alloimmunization in sickle cell anemia in the era of extended red cell typing. Pediatr Blood Cancer 2013; 60(9): 1487-1491.

[6] de Montalembert M, Dumont MD, Heilbronner C, Brousse V, Charrara O, Pellegrino B, Piguet C, Soussan V, NoizatPirenne F. Delayed hemolytic transfusion reaction in children with sickle cell disease. Haematologica 2011; 96(6): 801-807.

[7] Talano JA, Hillery CA, Gottschall JL, Baylerian DM, Scott JP. Delayed hemolytic transfusion reaction/hyperhemolysis syndrome in children with sickle cell disease. Pediatrics 2003; 111(6 Pt 1): e661-665.

[8] Dias Zanette AM, de Souza Gonçalves M, Vilasboas Schettin L, Magalhães Aguiar L, Santos Bahia RC,Vasconcelos Nogueira LA, de Freitas Brandão CJ, Neves de Azevedo AC, Ramos de Aragao L, Marcos Arruda S. Alloimmunization and clinical profile of sickle cell disease patients from Salvador - Brazil. Ethn Dis 2010; 20(2): 136-141.

[9] Natukunda B, Schonewille H, Ndugwa C, Brand A. Red blood cell alloimmunization in sickle cell disease patients in Uganda. Transfusion 2010; 50(1): 20-25.

[10] Bashawri LA. Red cell alloimmunization in sickle-cell anaemia patients. East Mediterr Health J 2007; 13(5): 1181 1189.

[11] AlSaeed $\mathrm{AH}$. The distribution of $\mathrm{ABO}$ and $\mathrm{Rh}$ blood groups in a sample of pregnant women in a sample of pregnant women in the Eastern Province of Saudi Arabia. Arab Gulf J Sci Res 1998; 16(2): 259-265

[12] Chou ST, Westhoff CM. The Rh system. In: Technical Manual. Roback JD, ed. Bethesda, MD: AABB; 2011: 389-410.

[13] Osby M, Shulman IA. Phenotype matching of donor red blood cell units for nonalloimmunized sickle cell disease patients: a survey of 1182 North American laboratories. Arch Pathol Lab Med 2005; 129(2): 190-193.

[14] Wahl S, Quirolo KC. Current issues in blood transfusion for sickle cell disease. Curr Opin Pediatr 2009; 21(1): 15-21.

[15] Rees DC, Williams TN, Gladwin MT. Sickle-cell disease. Lancet 2010; 376(9757): 2018-2031.

[16] Adams RJ, Brambilla D; Optimizing Primary Stroke Prevention in Sickle Cell Anemia (STOP 2) Trial Investigators. Discontinuing prophylactic transfusions used to prevent stroke in sickle cell disease. N Engl J Med 2005; 353(26): 2769-2778.
[17] Olujohungbe A, Hambleton I, Stephens L, Serjeant B, Serjeant G. Red cell antibodies in patients with homozygous sickle cell disease: a comparison of patients in Jamaica and the United Kingdom. Br J Haematol 2001; 113(3): 661-665.

[18] Ameen R, Al Shemmari S, Al-Bashir A. Red blood cell alloimmunization among sickle cell Kuwaiti Arab patients who received red blood cell transfusion. Transfusion 2009; 49(8): 1649-1654.

[19] Josephson CD, Su LL, Hillyer KL, Hillyer CD. Transfusion in the patient with sickle cell disease: a critical review of literature and transfusion guidelines. Transfus Med Rev 2007; 21(2): 118-133

[20] Rosse WF, Gallagher D, Kinney TR, Castro O, Dosik H, Moohr J, Wang W, Levy PS. Transfusion and alloimmunization in sickle cell disease. The Cooperative Study of Sickle Cell Disease. Blood 1990; 76(7): 1431-1437.

[21] Meny GM. Transfusion protocols for patients with sickle cell disease: working toward consensus? Immunohematology 2012; 28(1): 1-2

[22] Dunbar LN, Coleman Brown L, Rivera DR, Hartzema AG, Lotternberg R. Transfusion practice in management of sickle cell disease: a survey of Florida hematologists/ oncologist. ISRN Hematol 2012; 2012: 524513. 


\title{
تكوين أجسام مناعية عند مرضى الأنيميا المنجلية الذين يتلقون نقل الام بجدة، المملكة العربية السعودية: دراسة تجريبية.
}

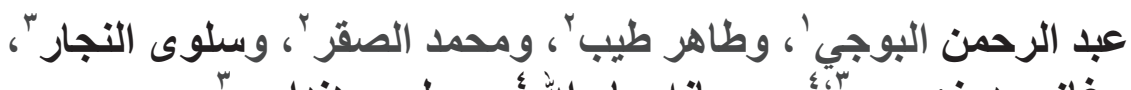

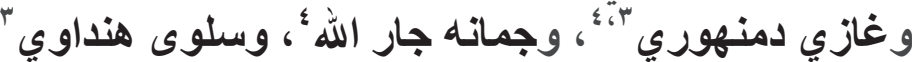

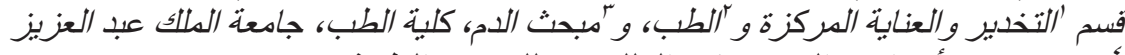

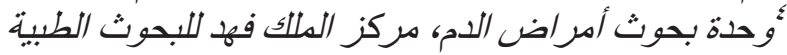 \\ جدة ـ المدلكة العربية السعودية العركية
}

المستخلص. كثير أ ما يحتاج مرضى الأنيميا المنجلية إلى نقل دم مما ينتج عنه تكون أجسام مناعية مضادة للكريات

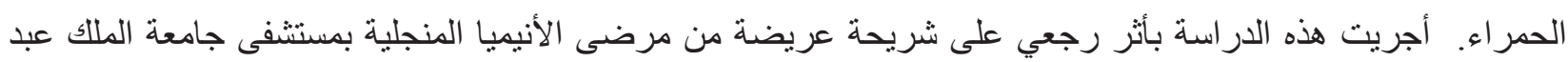

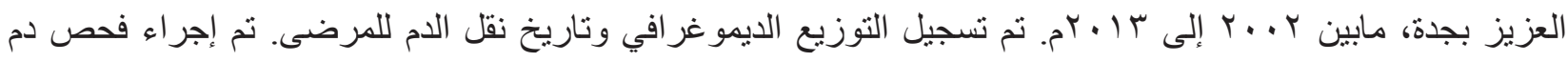

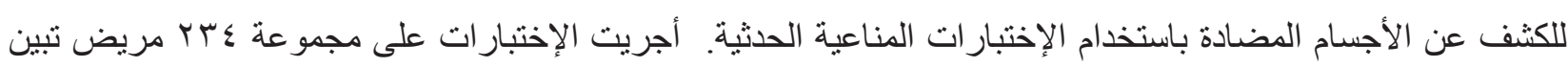

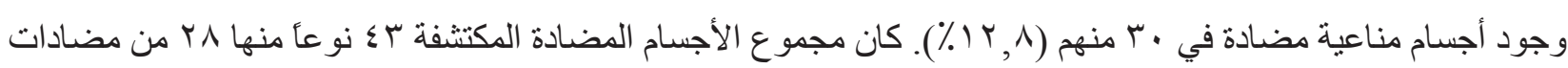
الفصيلة Kell بينما كان هناك ب حالات تنتمي إلى فئة MNS. نم تحليل التركيبة الديموغر افية وتاريخ نقل الدم بين المرضى الدي

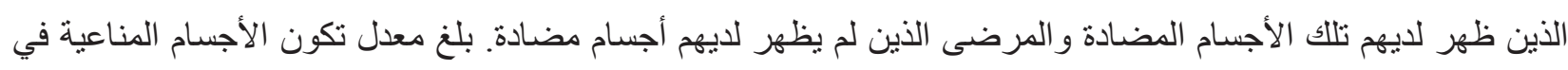

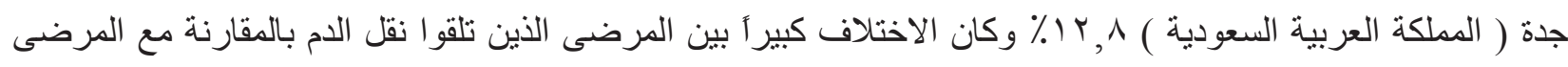

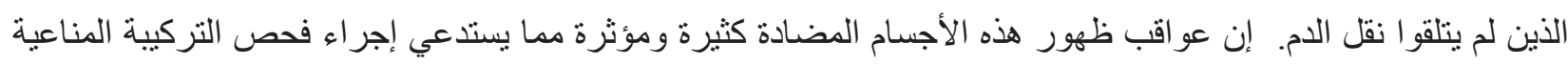

